\title{
PENGARUH MODEL PEMBELAJARAN DISCOVERY LEARNING PADA PEMBELAJARAN TEMATIK DI MI MA'ARIF PULUTAN
}

\author{
Rini Verary Shanthi, Nurul Maghfiroh \\ Fakultas Tarbiyah dan Ilmu Keguruan (FTIK) Institut Agama Islam Negeri (IAIN) \\ Salatiga \\ riniverary@iainsalatiga.ac.id
}

\begin{abstract}
Abstrak
Discovery learning merupakan suatu model pembelajaran yang melibatkan peserta didik dalam pemecahan masalah untuk pengembangan pengetahuan dan keterampilan. Penggunaan model pembelajaran discovery learning dapat melibatkan siswa dalam kegiatan pemecahan masalah, belajar mandiri, berpikir kritis, dan pemahaman serta belajar kreatif. Model pembelajaran discovery learning sejalan dengan pendekatan pembelajaran tematik. Pembelajaran tematik mengharuskan siswa belajar secara bersamaan. Pembelajaran tematik dirancang berdasarkan tema-tema tertentu secara terpadu untuk mengaitkan beberapa mata pelajaran sehingga dapat memberikan pengalaman bermakna kepada siswa. Penelitian ini bertujuan untuk mengetahui pengaruh model pembelajaran discovery learning pada pembelajaran tematik di MI Ma'arif Pulutan. Metode penelitian kualitatif digunakan dalam pelaksanaan penelitian ini. Sumber data primer diperoleh dari guru kelas dan hasil belajar siswa. Data sekunder diperoleh dari kepala sekolah dan waka kurikulum. Pengumpulan data dilakukan secara triangulasi (gabungan), analisis data bersifat kualitatif. Berdasarkan hasil penelitian diperoleh simpulan bahwa model pembelajaran discovery learning pada pendekatan pembelajaran tematik dapat mempermudah guru memberikan materi pada siswa, siswa mudah memahami materi, dan meningkatkan hasil belajar siswa di MI Ma'arif Pulutan.
\end{abstract}

Kata kunci: Discovery learning, pembelajaran tematik, pencapaian hasil belajar

\begin{abstract}
Discovery Learning is a learning model which makes students get involved in the problem solving for developing knowledge and skill. The using of discovery learning model can involve the students in problem solving activities, independent learning, thinking critically, comprehending and learning creatively. This learning model is along with thematic learning approach. The thematic learning is designed based on certain integrated themes to connect and correlate some subjects in order to give meaningful experiment for students. This research objects is to know the influence of discovery learning model to the thematic learning in MI Ma'arif Pulutan. The quaitative research methods was used in this reasearch. The primary data was collected from the teachers and the students' report of study. The secondary data was obtained from the principal and the vice of principal of curriculum. The data collection was processed by triangulation technique and the data analysis was processed by qualitative method. Based on the result of the research can be concluded that the discovery learning model on thematic learning approach can simplify the teacher to teach the students, the students can comprehend the material easily, and can increase the learning outcomes level of the students in MI Ma'arif Pulutan
\end{abstract}

Keywords: discovery learning, thematic learning, learning achievement 


\section{A. PENDAHULUAN}

Pendidikan adalah usaha sadar yang dilakukan seseorang untuk menjadi pribadi yang lebih baik dan mengembangkan potensi yang dimilikinya agar dapat bermanfaat bagi dirinya sendiri maupun orang lain dalam kehidupannya. ${ }^{1}$ Berbagai inovasi dilakukan dalam bidang pendidikan untuk meningkatkan kualitas sumber daya manusia Indonesia, salah satunya dengan menggunakan model pembelajaran discovery learning.

Model pembelajaran discovery learning dianggap dapat mengembangkan cara belajar siswa aktif melalui kegiatan menemukan dan menyelidiki suatu masalah, sehingga hasil yang diperoleh bertahan lama di dalam ingatan mereka (long term memory). ${ }^{2}$ Belajar penemuan atau discovery learning merupakan suatu pembelajaran yang melibatkan peserta didik dalam pemecahan masalah untuk pengembangan pengetahuan dan keterampilan. ${ }^{3}$ Penggunaan model pembelajaran discovery learning melibatkan siswa dalam kegiatan pemecahan masalah, belajar mandiri, berpikir kritis, dan pemahaman serta belajar kreatif. Model pembelajaran discovery learning merupakan satu rangkaian kegiatan pembelajaran yang melibatkan secara maksimal seluruh kemampuan siswa untuk mencari dan menyelidiki secara sistematis, kritis, dan logis sehingga mereka dapat menemukan sendiri pengetahuan, sikap, dan keterampilan sebagai wujud adanya perubahan perilaku.

Model pembelajaran discovery learning merupakan model pembelajaran yang didefinisikan sebagai proses pembelajaran yang terjadi bila siswa tidak disajikan dalam bentuk finalnya, diharapkan dapat mengorganisasi sendiri. ${ }^{4}$ Menurut Wulandari dkk pembelajaran discovery learning mempunyai langkah-langkah sebagai berikut:

1 Rosarina, G., Sudin, A., \& Sujana, A, Penerapan Model Discovery Learning Untuk Meningkatkan Hasil Belajar Siswa pada Materi Perubahan Wujud Benda, Jurnal Pena Ilmiah, 1(1).2016, hlm. 371

${ }^{2}$ Krisna, D.G.B., Ardiarta, A., \& Santiyandnya, N. e-Journal JPTE Universitas Pendididkan Ganesha, 4(1), 22-33. E-JournalJPTE Universitas Pendidikan Ganesha, 4(1). 2015, hlm.104.

${ }^{3}$ Anitah, S, Teknologi Pembelajaran, Surakarta: Yuma Pustaka, 2009, hlm. 55

${ }^{4}$ Kemendikbud.Model Pembelajaran Penemuan (Discovery Learning). Badan Pengembangan Sumber Daya Manusia Pendidikan dan Kebudayaan dan Penjaminan Mutu Pendidikan, Kementerian Pendidikan dan Kebudayaan. Jakarta. 2013 hlm 2. 
1. Identifikasi masalah, pada tahap ini guru memberikan kesempatan kepada siswa untuk mencari dan mengumpulkan sebanyak mungkin masalah yang berhubungan dengan tema yang akan dipelajari.

2. Mengembangkan kemungkinan solusi (hipotesis), pada tahap ini siswa diajak untuk membuat suatu hipotesis atas masalah yang telah ditentukan sebelumnya.

3. Pengumpulan data, pada tahap ini guru memberikan waktu kepada siswa untuk mengumpulkan data yang terkait dengan masalah. Data tersebut bisa dari observasi langsung, internet, buku, eksperimen, ataupun sumber-sumber yang lain.

4. Analisis dan interpretasi data, pada tahap ini siswa menganalisis data hasil temuannya, lalu mengembangkan pernyataan pendukung data. Setelah itu data diuji hipotesis dan disimpulkan.

5. Uji simpulan, setelah ada simpulan dari siswa, muncul data baru dan di tahap ini dilakukan pengujian terhadap hasil simpulan. Jika terjadi kekurangan dapat dilakukan revisi simpulan tersebut. ${ }^{5}$

Pelaksanaan pembelajaran dengan menerapkan model discovery learning dapat meningkatkan hasil belajar siswa tentang sumber daya alam di kelas IV SDN Gudangkopi. ${ }^{6}$ Hasil penelitian oleh Resnani menyatakan penerapan model discovery learning pada pembelajaran tematik kelas V CSDIT Generasi Rabbani kota Bengkulu dapat meningkatkan aktivitas pembelajaran baik aktivitas guru maupun aktivitas siswa dan meningkatkan hasil belajar siswa. ${ }^{7}$ Melalui model discovery learning siswa menjadi lebih dekat dengan apa yang menjadi sumber belajarnya, rasa percaya diri siswa akan meningkat karena dia merasa apa yang telah dipahaminya ditemukan oleh dirinya sendiri, kerjasama dengan temannya pun akan meningkat, serta menambah pengalaman siswa.

Pembelajaran di Sekolah Dasar/Madrasah Ibtidaiyah (MI) saat ini menggunakan pembelajaran pendekatan tematik, yang mengharuskan siswa belajar

${ }^{5}$ Wulandari, Y. I., Sunarto, \& Totalia, S. A. Implementasi Model Discovery Learning dengan Pendekatan Saintifik Untuk Meningkatkan Kemampuan Berfikir Kritis dan Hasil Belajar Siswa Mata Pelajaran Ekonomi Kelas XI IPS 1 SMA Negeri 6 Surakarta Tahun Pelajaran 2014/2015, Surakarta: FKIP Universitas Sebelas Maret, 2015, hlm.8

6 Rosarina, G., Sudin, A., \& Sujana, A, Penerapan Model Discovery Learning Untuk Meningkatkan Hasil Belajar Siswa pada Materi Perubahan Wujud Benda, Jurnal Pena Ilmiah, 1(1).2016, hlm. 379

${ }^{7}$ Resnani, Penerapan Model Discovery Learning untuk Peningkatan Aktivitas dan Hasil Belajar Siswa Pada Pembelajaran Tematik Kelas VC SDIT Generasi Rabbani Kota Bengkulu, Jurnal Pendidikan Guru Sekolah Dasar, 12(1), 2018, hlm.13 
secara bersamaan. Pembelajaran tematik adalah pembelajaran yang dirancang berdasarkan tema-tema tertentu, dalam pengertian lain pembelajaran tematik adalah pembelajaran terpadu yang menggunakan tema untuk mengaitkan beberapa mata pelajaran sehingga dapat memberikan pengalaman bermakna kepada siswa. Pembelajaran tematik adalah pembelajaran yang diawali dengan suatu tema tertentu yang mengaitkan dengan pokok bahasan lain, konsep tertentu dikaitkan dengan konsep lain yang dilakukan secara spontan atau direncanakan baik dalam satu bidang studi atau lebih dengan beragam pengalaman belajar sehingga pembelajaran menjadi semakin bermakna. ${ }^{8}$ Menurut Haji tema dalam pembelajaran tematik adalah pokok pikiran atau gagasan pokok yang menjadi bahasan dalam pembelajaran. Pembahasan tema ditinjau dari berbagai mata pelajaran. Sebagai contoh, tema "Air" dapat ditinjau dari mata pelajaran Ilmu Pengetahuan Alam dan Matematika. Lebih luas lagi, tema itu dapat ditinjau dari bidang studi lain, seperti Ilmu Pengetahuan Sosial, Bahasa, dan Seni.

Pembelajaran tematik menyediakan keluasan dan kedalaman implementasi kurikulum, menawarkan kesempatan yang sangat banyak pada siswa untuk memunculkan dinamika dalam pendidikan. Unit yang tematik adalah epitome dari seluruh bahasa pembelajaran yang memfasilitasi siswa untuk secara produktif menjawab pertanyaan yang dimunculkan sendiri dan memuaskan rasa ingin tahu dengan penghayatan secara alamiah tentang dunia di sekitar mereka. ${ }^{9}$ Prinsip pembelajaran tematik yang diterapkan di SD/MI dalam kurikulum 2013 berlandasan pada Permendikbud Nomor 65 Tahun 2013 yaitu:

1. Pembelajaran tematik integratif memiliki satu tema yang aktual dekat dengan dunia siswa dan ada dalam kehidupan sehari-hari. tema ini menjadi satu pemersatu materi yang beragam dari beberapa mata pelajaran.

2. Pembelajaran tematik integratif perlu memilih materi beberapa mata pelajaran yang mungkin saling terkait. Dengan demikian materi-materi yang dipilih dapat mengungkapkan tema secara bermakna. Mungkin terjadi pengayaan horizontal dalam bentuk contoh aplikasi yang tidak termuat dalam standart isi.

\footnotetext{
${ }^{8}$ Munawaroh, I, Pembelajaran Tematik dan Aplikasinya di Sekolah Dasar (SD), Forum Ilmiah Guru SD, 1-23, Yogyakarta: Staff UNY, 2016, hlm.7

${ }^{9}$ Haji, S, Pembelajaran Tematik yang Ideal di SD/MI, Jurnal Stit Nu Alhikmah, III(1), 57-69, 2015, hlm.60
} 
3. Pembelajaran tematik integratif tidak boleh bertentangan dengan tujuan kurikulum yang berlaku tetapi sebaliknya pembelajaran tematik integratif harus mendukung pencapaian tujuan utuh kegiatan pembelajaran yang termuat dalam kurikulum.

4. Materi pembelajaran yang dapat dipadukan dalam satu tema selalu mempertimbangkan karakteristik siswa seperti minat, kemampuan, kebutuhan dan pengetahuan awal.

5. Materi awal yang dipadukan tidak terlalu dipaksakan. Artinya, materi yang tidak mungkin dipadukan tidak usah dipadukan. ${ }^{10}$

Pembelajaran tematik dimaksudkan agar pembelajaran lebih bermakna dan utuh. Pembelajaran tematik ini memiliki peran yang sangat penting dalam meningkatkan perhatian, aktivitas belajar, dan pemahaman siswa terhadap materi yang dipelajarinya, karena pembelajaran lebih berpusat pada siswa, memberikan pengalaman langsung kepada siswa, pemisahan mata pelajaran tidak begitu jelas dalam menyajikan konsep dari berbagai mata pelajaran dalam suatu proses pembelajaran, bersifat fleksibel, hasil pembelajaran dapat berkembang sesuai dengan minat, dan kebutuhan siswa. ${ }^{11}$

Menurut Sukayati pembelajaran tematik di SD merupakan terapan dari pembelajaran terpadu. Berdasarkan sejumlah temuan model pembelajaran oleh Fogarty terdapat tiga model yang sesuai dengan kurikulum SD tentang cara memadukan konsep, keterampilan dan unit tematis pada pembelajaran tematik yang terpadu. ${ }^{12}$

Model hubungan (Connected model) yaitu menghubungkan suatu topik dengan topik berikutnya dalam bidang kajian satu disiplin ilmu. Siswa memperoleh gambaran menyeluruh tentang suatu konsep dan pengembangan konsep tersebut.

1. Model terjala (Webbed model) yaitu guru dan siswa memilih suatu tema, kemudian dilanjutkan dengan sub-sub tema dengan menghubungkan antar disiplin ilmu/ mata pelajaran. Siswa memperoleh pandangan yang utuh dari suatu tema/kegiatan ditinjau dari ilmu yang berbeda-beda.

${ }^{10}$ Hidayah, N, Pembelajaran Tematik Integratif di Sekolah Dasar, Terampil Pendidikan Dan Pembelajaran Dasar, 2(1), 2015, hlm 38

${ }^{11}$ Sungkono, Pembelajaran Tematik dan Implementasinya di Sekolah Dasar, Majalah Ilmiah Pembelajaran, 2(1), 2006, hlm.58

${ }^{12}$ Sukayati, Pembelajaran Tematik Di SD Merupakan Terapan Dari Pembelajaran Terpadu, Departemen Pendidikan Nasional Direktorat Jenderal Pendidikan Dasar dan Menengah Pusat Pengembangan Penataran Guru (PPPG) Matematika, Yogyakarta, 2004, hlm 5 
2. Model terpadu (Integrated model) dilakukan dengan menggabungkan beberapa mata pelajaran, menetapkan prioritas dari kurikulum. Guru memilih konsep, keterampilan dan nilai sikap pada beberapa mata pelajaran, kemudian dipilih konsep keterampilan dan nilai sikap yang memiliki hubungan erat dengan mata pelajaran sebelumnya. Sehingga siswa mudah menghubungkan materi dari beberapa mata pelajaran.

Keberhasilan pembelajaran tematik agar dapat terlaksana dengan baik harus memperhatikan keterpaduan tema dan perlu ditempuh dengan tahap perencanaan, penerapan dan evaluasi sesuai dengan model pembelajaran yang dipilih. Dengan demikian pelaksanaan pembelajaran di kelas dapat terkonsep secara matang serta menunjang kesiapan guru dan siswa dalam proses belajar.

Sekolah MI Ma'arif Pulutan merupakan salah satu sekolah yang menerapkan pembelajaran tematik. Berdasarkan observasi awal, beberapa guru telah menggunakan model pembelajaran discovery learning dalam pendekatan belajar tematik. Oleh karena itu, penelitian ini bertujuan untuk melihat pengaruh penggunaan model pembelajaran discovery learning pada pembelajaran tematik di MI Ma'arif Pulutan.

\section{B. METODE PENELITIAN}

Penelitian ini dilaksanakan dengan metode penelitian kualitatif. Metode penelitian kualitatif digunakan untuk meneliti pada kondisi obyek yang alamiah. Peneliti sebagai instrumen kunci, teknik pengumpulan data dilakukan secara triangulasi (gabungan), analisis data bersifat kualitatif dan lebih menekankan pada makna daripada generalisasi. ${ }^{13}$ Sumber data primer diperoleh dari guru kelas dan hasil belajar siswa. Data sekunder diperoleh dari kepala sekolah dan waka kurikulum. Pengumpulan data dilakukan melalui observasi, kuisioner, dan dokumentasi.

Observasi dilakukan secara partisipasi pasif, yaitu peneliti melakukan pengamatan pembelajaran di MI Ma'arif Pulutan tanpa terlibat dalam pembelajaran tersebut. Pengambilan data kuisioner dilakukan secara terstruktur melalui lembar kuisioner menggunakan pertanyaan yang sama pada semua guru di MI Ma'arif Pulutan. Dokumentasi berupa perangkat pembelajaran guru, hasil belajar siswa dan pengambilan beberapa foto saat penelitian digunakan untuk melengkapi data observasi hlm. 225

13 Sugiyono, Metode Penelitian Kualitataif, Kuantitatif, dan R\&D, Bandung: Alfabeta, 2016, 
dan data hasil kuisioner. Analisis data yang digunakan dalam penelitian ini menggunakan deskriptif analitis, untuk menjelaskan tentang hasil penelitian berupa pengaruh model pembelajaran discovery learning pada pembelajaran tematik di MI Ma'arif Pulutan.

\section{HASIL DAN PEMBAHASAN}

Pembelajaran tematik merupakan pendekatan pembelajaran yang mengintegrasikan kompetensi dari berbagai mata pelajaran ke dalam berbagai tema. Menurut Kemdikbud pengintegrasian tersebut dilakukan dalam dua hal yaitu integrasi sikap, keterampilan, dan pengetahuan dalam proses pembelajaran dan integrasi berbagai konsep dasar yang berkaitan. Hasil observasi di MI Ma'arif Pulutan, seluruh kelas menggunakan pembelajaran dengan pendekatan pembelajaran tematik.

Pendekatan pembelajaran tematik di sekolah ini memperhatikan tahapan perkembangan berfikir siswa usia sekolah dasar. Menurut Haji kecenderungan belajar anak usia sekolah dasar memiliki tiga ciri, yaitu:

1. Konkrit, yakni belajar yang dapat dilihat, didengar, dibaui dan diotak atik dengan pemanfaatan lingkungan sebagai sumber belajar. Pemanfaatan lingkungan akan menghasilkan proses dan hasil belajar yang lebih bermakna dan bernilai. Siswa dihadapkan dengan peristiwa dan keadaan yang alami dan sebenarnya, lebih faktual, lebih bermakna, dan dapat dipertanggungjawabkan.

2. Integratif, dengan memandang sesuatu yang dipelajari sebagai suatu keutuhan, mereka belum mampu memilah-milah konsep dari berbagai disiplin ilmu, hal ini melukiskan cara berpikir anak yang deduktif yakni dari hal umum ke bagian demi bagian.

3. Hirarkis, cara anak belajar berkembang secara bertahap mulai dari hal-hal yang sederhana ke hal-hal yang lebih kompleks. Perlu diperhatikan mengenai urutan logis, keterkaitan antar materi, dan cakupan keluasan serta kedalaman materi.

Guru mengemas pembelajaran tematik sesuai dengan ketiga hal tersebut. Mengaitkan pembelajaran dengan hal yang kongkrit/ kejadian dalam kehidupan seharihari. Beberapa konsep disusun secara integratif, yaitu mengaitkan tema kehidupan sehari-hari dengan beberapa disiplin ilmu/mata pelajaran. Penyampaian materi pelajaran diberikan secara hierarkis dimulai dari hal yang sederhana/sub tema menuju hal yang komplek. 
Tahun ajaran 2019-2020 terdapat 23 kelas di sekolah ini dengan jumlah siswa setiap kelas berkisar 20-28 siswa. Terdapat 23 guru kelas dilengkapi dengan 10 guru mata pelajaran serta guru olah raga. Keseluruhan kelas sudah melaksanakan pendekatan pembelajaran tematik sesuai dengan kurikulum 2013. Pelaksanaan pembelajaran tematik dilakukan sesuai dengan acuan dari Kemendikbud melalui tahaptahap berikut: menentukan tema, mengintegrasikan tema dengan kurikulum, mendesain rencana pembelajaran, kemudian melaksanakan aktivitas pembelajaran. Sesuai dengan kerangka dasar dan struktur kurikulum yang dikeluarkan oleh Badan Standar Nasional Pendidikan, mata pelajaran yang harus dicakup pada pembelajaran tematik meliputi: (1) pendidikan agama, (2) pendidikan kewarganegaraan, (3) bahasa indonesia, (4) matematika, (5) ilmu pengetahuan alam, (6) ilmu pengetahuan sosial, (7) seni budaya dan keterampilan, (8) pendidikan jasmani, olahraga, dan kesehatan. ${ }^{14}$ Pembelajaran tematik pada kurikulum 2013 menekankan pada pembelajaran dengan penilaian proses aktivitas belajar dari pengetahuan, sikap, dan keterampilan. Penilaian pengetahuan dilakukan menggunakan tes/penugasan. Penilaian sikap melalui observasi, penilaian diri, penilaian antar teman, dan jurnal dari guru. Penilaian keterampilan dilakukan menggunakan penilaian kinerja, projek, serta portofolio.

Pendekatan pembelajaran tematik memerlukan guru yang kreatif dalam menyiapkan kegiatan pembelajaran sehingga materi dapat tersampaikan secara utuh dengan mengaitkan berbagai disiplin ilmu/ mata pelajaran. Pembelajaran tematik di MI Ma'arif Pulutan didukung dengan alat peraga seperti: peta dunia, alat peraga matematika, rangka manusia, dan perlengkapan praktikum sederhana yang disiapkan oleh guru. Lingkungan sekolah juga digunakan sebagai obyek pengamatan karena masih alami. Tumbuhan dan hewan-hewan kecil seperti belalang, ulat, kupu-kupu, capung, semut, ayam, burung gereja dapat dijumpai di lingkungan sekitar sekolah. Tempat ibadah juga disediakan untuk beribadah dan kegiatan pembelajaran terkait dengan ilmu agama.

Pembelajaran tematik menekankan pada proses aktivitas siswa. Pelaksanaan pembelajaran tematik menggunakan metode dan strategi yang berpusat pada siswa

${ }^{14}$ Hidayah, N. Pembelajaran Tematik Integratif di Sekolah Dasar. Terampil Pendidikan Dan Pembelajaran Dasar, 2(1) 2015 hlm 44. 
sesuai dengan tingkat perkembangan siswa. Model pembelajaran discovery learning tepat digunakan dalam pembelajaran tematik. Model pembelajaran ini mengarahkan siswa untuk menemukan konsep melalui penemuan yang diperoleh. Sehingga, kegiatan pembelajaran berpusat pada aktivitas siswa. Oleh karena itu, pengalaman belajar dapat membuat siswa lebih berkesan dan mengingat materi dengan ingatan jangka panjang.

Kuisioner dalam penelitian ini diberikan kepada 23 guru kelas. Data hasil kuisioner kepada 23 guru kelas di MI Ma'arif Pulutan, diperoleh 74\% guru atau sejumlah 17 guru menggunakan model pembelajaran discovery learning. Selain itu, hasil kuisioner guru juga menyatakan seluruh hasil belajar siswa di atas Kriteria Ketuntasan Miniman (KKM) dengan batas nilai adalah 70. Jadi, siswa mudah dalam menerima materi melalui model pembelajran discovery learning pada pembelajaran tematik. Sejumlah guru yang menerapkan model pembelajaran tersebut adalah guru kelas II sampai kelas VI. Guru yang tidak menerapkan adalah guru kelas I. Hal ini dikarenakan guru merasa kesulitan dalam menerapkan model pembelajaran pada siswa kelas I. Untuk siswa kelas I, pembelajaran masih terpusat pada guru. Hasil kuisioner tentang penerapan model pembelajaran discovery learning oleh guru MI Ma'arif pulutan ditunjukkan oleh Gambar 1.

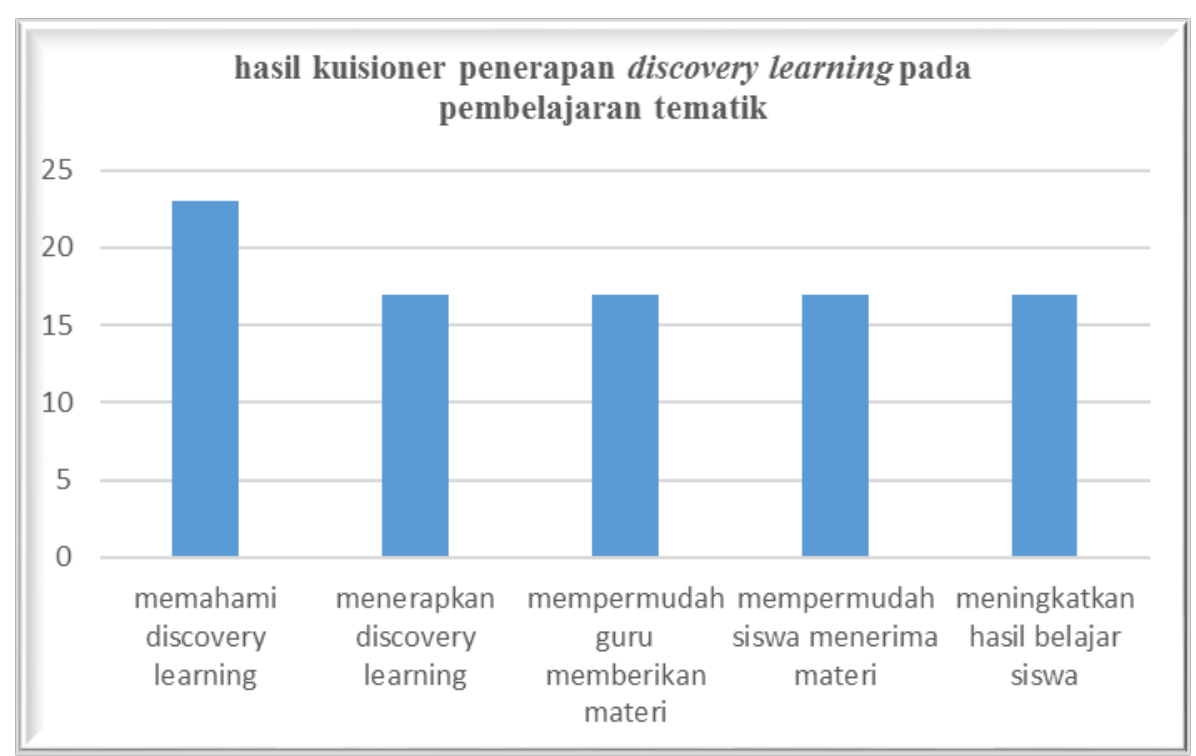

Gambar 1. Data hasil kuisioner penerapan model pembelajaran discovery learning oleh guru MI Ma'arif Pulutan 
Penerapan model pembelajaran discovery learning pada pendekatan tematik di MI Ma'arif Pulutan disesuaikan dengan standar kompetensi, kompetensi dasar dan indikator serta keterampilan siswa yang ingin dinilai. Pembelajaran diawali dengan kegiatan pendahuluan untuk menciptakan suasana belajar dan memfokuskan siswa terhadap materi yang akan dipelajari. Guru menggali pengetahuan awal siswa dengan pertanyaan atau meminta siswa mendeskripsikan suatu tema. Kemudian, kegiatan inti dilakuan untuk mengembangkan kemampuan siswa dan menyampaikan siswa pada materi inti. Kegiatan ini dapat dilakukan dengan interaksi kelompok kecil yang dibentuk sesuai model discovery learning. Selanjutnya, diakhiri dengan menyimpulkan dan mengevaluasi hasil pembelajaran dengan bimbingan guru. Kegiatan penutup tersebut bertujuan untuk menyamakan konsep antar siswa dan guru.

Pembelajaran dengan model discovery learning di MI Ma'arif Pulutan tidak sepenuhnya diterapkan untuk seluruh tema pembelajaran. Model discovery learning diterapkan untuk beberapa tema yang terkait dengan alam atau yang bisa diberikan praktikum/ pengamatan. Contohnya, pembelajaran dengan tema gerak benda pada pembelajaran kelas IV. Guru menyusun perangkat pembelajaran sesuai dengan tahapan dari model discovery learning. Tahapan yang dilakukan guru pada penelitian ini dalam Tabel 1.

Tabel 1. Tahapan pelaksanaan pembelajaran discovery learning oleh guru

\begin{tabular}{|l|l|}
\hline \multicolumn{1}{|c|}{ Kegiatan } & \multicolumn{1}{c|}{ Jenis kegiatan } \\
\hline Kegiatan & $\begin{array}{l}\text { Guru menyampaikan tema materi yang akan } \\
\text { dipelajari. } \\
\text { Guru meminta siswa untuk membentuk 6 kelompok } \\
\text { dan melakukan penemuan pada materi gerak benda. }\end{array}$ \\
\hline Kegiatan inti & $\begin{array}{l}\text { Guru memberikan contoh dengan alat peraga. } \\
\text { Siswa menjawab pertanyaan yang diberikan guru. } \\
\text { Siswa berdiskusi dengan teman sekelompoknya. } \\
\text { Kemudian setiap kelompok mencari benda yang } \\
\text { dapat bergerak dengan bimbingan dari guru. }\end{array}$ \\
& \begin{tabular}{l} 
Perwakilan kelompok maju untuk \\
\hline
\end{tabular} \\
\hline
\end{tabular}




\begin{tabular}{|l|l|}
\hline & mengkomunikasikan hasil dari pengamatannya. \\
\hline Kegiatan penutup & $\begin{array}{l}\text { Guru memberikan kesimpulan. } \\
\text { Evaluasi. } \\
\text { Penutup }\end{array}$ \\
\hline
\end{tabular}

Langkah-langkah tersebut sesuai dengan acuan langkah operasional yang disusun oleh Kementerian Pendidikan dan Kebudayaan. Langkah operasional discovery learning dilaksanakan berdasarkan tahapan seperti pada skema Gambar 2.

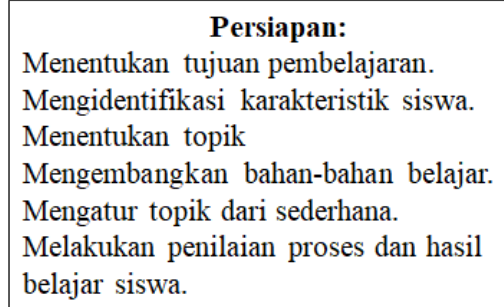

\section{Pelaksanaan:}

Stimulasi/ pemberian rangsangan.

Pernyataan/ identifikasi masalah oleh

siswa.

Pengumpulan data oleh siswa.

Pengolahan data dari informasi/

pengetahuan siswa.

Verification/ pembuktian.

Menarik kesimpulan/ generalisasi.

Gambar 2. Skema langkah operasional pelaksanaan pembelajaran model discovery learning.

Sistem penilaian pada model pembelajaran discovery learning dapat dilakukan menggunakan tes atau non tes. Menurut kemendikbud dalam penjelasan model pembelajaran discovery learning, penilaian berupa penilaian kognitif, proses, sikap, dan kinerja siswa. Tahap evaluasi siswa yang dilakukan oleh guru di MI Ma'arif Pulutan dilakukan dengan kegiatan tes/ penugasan pada sub tema yang dipelajari. Hasil observasi dan wawancara kepada guru kelas di MI Ma'arif Pulutan menyatakan bahwa hasil belajar siswa seluruhnya mencapai KKM. Menggunakan model discovery learning, juga meningkatkan keaktifan siswa dalam proses pembelajaran, sehingga mampu meningkatkan hasil belajar siswa serta menunjang stimulus dalam mengkaji ilmu pengetahuan.

Keaktifan siswa adalah wujud dari rasa tanggung jawab dalam belajar. Interaksi sesama teman saat proses pembelajaran dapat melatih siswa menghargai pendapat teman. Proses ini melatih siswa berani mengemukakan pendapat, berani menarik kesimpulan, dan melatih kerjasama. Pada penilaian sikap, aktivitas siswa menunjukan perilaku ilmiah. Materi yang disajikan pada pendahuluan mendorong siswa merasa ingin tahu. Kemudian, berkembang menjadi sifat kritis, yaitu mencari 
informasi dari berbagai sumber. Siswa akan bersikap terbuka menerima penjelasan dari teman/ guru. Hal ini membuat kerangka berfikir secara obyektif dan mampu merumuskan konsep. Konsep pembelajaran yang ditemukan berdasarkan pengalaman siswa tersebut akan memperkaya informasi dan mendukung aktivitas belajar siswa. Keaktifan siswa saat melaksanakan proses belajar membuat siswa merasa berkesan dan tertarik. Siswa yang aktif dalam pembelajaran, dapat mengingat pemahaman materi dengan baik. Dengan demikian model pembelajaran ini sangat efektif diterapkan pada tema-tema tertentu pada pembelajaran dengan pendekatan tematik.

Penggunaan model pembelajaran discovery learning pada pembelajaran tematik memiliki beberapa kelebihan dan juga kelemahan. Beberapa kelebihan dalam model pembelajaran ini adalah tertulis di bawah ini:

1. Meningkatkan keterampilan dan proses kognitif siswa.

2. Menimbulkan rasa senang dan tumbuh rasa ingin tahu/ menyelidiki suatu materi.

3. Meningkatkan rasa percaya diri siswa.

4. Siswa mudah mengingat materi dengan ingatan jangka panjang.

5. Mempermudah guru dalam mentransfer materi kepada siswa.

Kelemahan model pembelajaran discovery learning pada pendekatan pembelajaran tematik meliputi:

1. Kurang efisien jika diterapkan dengan siswa dalam jumlah yang banyak.

2. Siswa harus memiliki kesiapan dalam pembelajaran discovery sehingga dapat menghubungkan antar konsep.

3. Model pembelajaran ini hanya tepat digunakan pada tema-tema tertentu, yang terkait dengan alam/praktikum.

\section{SIMPULAN}

Model pembelajaran discovery learning memberikan kesempatan kepada siswa untuk menemukan sebuah konsep dan memecahkan masalah melalui skenario pembelajaran yang telah disiapkan oleh guru. Kegiatan yang dialami siswa adalah berinteraksi untuk mencari konsep selama pembelajaran/bereksperimen. Model pembelajaran discovery learning dapat diterapkan pada pembelajaran pendekatan tematik karena pembelajaran tematik menekankan pada proses aktivitas siswa. Pembelajaran tematik diawali dengan suatu tema tertentu yang mengaitkan dengan 
pokok bahasan lain, konsep tertentu dikaitkan dengan konsep baik dalam satu bidang studi atau lebih dengan beragam pengalaman belajar sehingga pembelajaran menjadi semakin bermakna.

Hasil penelitian yang dilaksanakan di MI Ma'arif Pulutan terdapat 74\% guru kelas menggunakan model pembelajaran discovery learning pada beberapa tema dalam pendekatan pembelajaran tematik. Guru menggunakan model pembelajaran discovery learning pada beberapa tema yang dianggap sesuai. Selain menyusun skenario pembelajaran, guru juga menyiapkan perangkat pembelajaran atau alat peraga yang sesuai dengan model pembelajaran. Model pembelajaran tersebut memberikan kemudahan bagi guru terutama dalam memberikan atau menyampaikan materi kepada siswa. Hasil observasi dan data hasil kuisioner dapat disimpulkan bahwa menggunakan model pembelajaran discovery learning dapat memudahkan siswa menerima materi. Hasil belajar siswa mencapai KKM dengan batas nilai 70 . Saat proses pembelajaran, siswa sangat aktif. Keaktifan siswa ini dapat dilihat dari berbagai kegiatan yaitu melatih rasa tanggung jawab, berani mengemukakan pendapat, menghargai pendapat siswa lain, dan mampu menarik kesimpulan dengan baik. Interaksi sesama siswa saat proses pembelajaran dapat menumbuhkan perilaku ilmiah.

Penggunaan model pembelajaran discovery learning pada pembelajaran tematik di MI Ma'arif Pulutan memiliki beberapa kelebihan dan juga kekurangan. Kelebihan pada penggunaan model pembelajaran discovery learning dapat meningkatkan keterampilan dan proses kognitif atau pemahaman siswa melalui usaha penemuan, menumbuhkan rasa ingin tahu dan rasa percaya diri, memudahkan guru menyampaikan materi, serta memudahkan siswa mengingat materi dengan ingatan jangka panjang. Model pembelajaran discovery learning memiliki kekurangan terutama dengan pendekatan pembelajaran tematik hingga menjadikan model pembelajaran ini kurang efisien jika diterapkan dengan siswa dalam jumlah yang banyak. Kekurangan lain dari model pembelajaran ini adalah siswa harus memiliki kesiapan terutama kesiapan dalam berbagai hal dalam proses pembelajaran. Model pembelajaran discovery learning umumnya hanya tepat digunakan pada tema-tema tertentu yakni tema-tema yang berkaitan dengan alam 
atau kegiatan praktikum dan tema-tema lain yang membutuhkan proses pengamatan secara seksama. 


\section{DAFTAR PUSTAKA}

Anitah, S, Teknologi Pembelajaran, Surakarta: Yuma Pustaka, 2009

Haji, S, Pembelajaran Tematik yang Ideal di SD/MI. Jurnal STIT NU Alhikmah, III(1), 2015

Hidayah, N, Pembelajaran Tematik Integratif di Sekolah Dasar, Terampil Pendidikan dan Pembelajaran Dasar, 2(1), 2015

Kemendikbud, Modul Pelatihan Implementasi Kurikulum 2013, Jakarta: Badan Pengembangan Sumber Daya Manusia Pendidikan dan Kebudayaan dan Penjaminan Mutu Pendidikan, Kementerian Pendidikan dan Kebudayaan, 2013

, Model Pembelajaran Penemuan (Discovery Learning), Jakarta: Badan Pengembangan Sumber Daya Manusia Pendidikan dan Kebudayaan dan Penjaminan Mutu Pendidikan, Kementerian Pendidikan dan Kebudayaan, 2013

Krisna, D.G.B., Ardiarta, A., \& Santiyandnya, N. e-Journal JPTE Universitas Pendididkan Ganesha, E-Journal JPTE Universitas Pendidikan Ganesha, 4(1), 2015

Munawaroh, I. Pembelajaran Tematik dan Aplikasinya di Sekolah Dasar (SD), Yogyakarta: Forum Ilmiah Guru SD, 2016

Resnani, Penerapan Model Discovery Learning untuk Peningkatan Aktivitas dan Hasil Belajar Siswa Pada Pembelajaran Tematik Kelas VC SDIT Generasi Rabbani Kota Bengkulu. Jurnal Pendidikan Guru Sekolah Dasar, 12(1), 2018

Rosarina, G., Sudin, A., \& Sujana, A, Penerapan Model Discovery Learning Untuk Meningkatkan Hasil Belajar Siswa pada Materi Perubahan Wujud Benda, Jurnal Pena Ilmiah, 1(1), 2016

Sugiyono, Metode Penelitian Kualitataif, Kuantitatif, dan R\&D, Bandung: Alfabeta, 2016

Sukayati, Pembelajaran Tematik Di SD Merupakan Terapan Dari Pembelajaran Terpadu. Departemen Pendidikan Nasional Direktorat Jenderal Pendidikan Dasar dan Menengah Pusat Pengembangan Penataran Guru (PPPG) Matematika, Yogyakarta, 2004

Sungkono, Pembelajaran Tematik dan Implementasinya di Sekolah Dasar, Majalah Ilmiah Pembelajaran 2(1), 2006

Wulandari, Y. I., Sunarto, \& Totalia, S. A, Implementasi Model Discovery Learning dengan Pendekatan Saintifik Untuk Meningkatkan Kemampuan Berfikir Kritis dan Hasil Belajar Siswa Mata Pelajaran Ekonomi Kelas XI IPS 1 SMA Negeri 6 Surakarta Tahun Pelajaran 2014/2015, Surakarta: FKIP Universitas Sebelas Maret, 2015 